\title{
Analisis Peneriman Sistem Ujian CBT Menggunakan Metode UTAUT (Unified Theory of Acceptance and Use of Technology) di Lingkungan Kampus
}

\author{
Arjuna Ginting ${ }^{1}$, Roslina $^{2}$, Wanayumini ${ }^{1}$ \\ ${ }^{1}$ Fakultas Teknik dan Ilmu Komputer, Prodi Magister Ilmu Komputer, Universitas Potensi Utama, Medan, Indonesia \\ ${ }^{2}$ Politeknik Negeri Medan, Medan, Indonesia \\ Email: ${ }^{1}$ arjunagintingsuka87@gmail.com, ${ }^{2}$ roslinanich@gmail.com, ${ }^{3}$ wanayumini@gmail.com \\ Email Penulis Korespondensi: arjunagintingsuka87@gmail.com
}

\begin{abstract}
Abstrak-Teknologi sistem informasi telah di terapkan ke dalam semua organisasi, baik organisasi maupun nirlaba, bahkan tidak luput pada perkembangan teknologi informasi ini telah dirasakan oleh bidang pendidikan. Perlahan teknologi mulai menggantikan beberapa pekerjaan dan aktivitas yang dilakukan oleh manusia. Namun, teknologi sekarang masih belum sempurna pengaplikasiannya. Penelitian ini mencoba untuk mendapatkan gambaran bagaimana tanggapan peserta yang menggunakan teknologi komputer dalam menjalankan proses ujian mereka atau lebih dikenal ujian berbasis Computer Based Test (CBT). Responden dipilih sebanyak 100 orang yang bersedia untuk melakukan mengisi kuesioner penelitian. Untuk mendapatkan hasil analisa yang baik, penelitian ini menggunakan metode penyelesaian masalah yaitu dengan menggunakan Unified Theory Acceptance and Use of Technology (UTAUT) dengan bermacam-macam konstruk. Hasilnya, metode UTAUT menjelaskan penerimaan pengguna CBT dengan konstruk ekspektasi usaha ekspektasi kinerja (PE) berpengaruh signifikan terhadap penerimaan dan penggunaan suatu sistem (BIUS). Untuk mengukur tingkat variasi perubahan variabel independen terhadap variabel dependen atau nilai R-Square tertinggi dalam metode UTAUT yaitu sebesar 73\%. Dari hasil tersebut dapat disimpulkan bahwa metode UTAUT merupakan metode yang paling baik digunakan dalam penelitian studi kasus ini.
\end{abstract}

Kata Kunci: Computer Based Test (CBT); Unified Theory Acceptance and Use of Technology (UTAUT); Analisis Jalur (Path); Aplikasi SEM PLS; Uji Hipotesis

\begin{abstract}
Information system technology has been applied to all organizations, both organizations and non-profits, even though the development of information technology has been felt by the education sector. Slowly technology began to replace some of the work and activities carried out by humans. However, today's technology is still not perfectly applied. This study tries to get an idea of how the participants respond using computer technology in carrying out their exam process or better known as the Computer Based Test (CBT) based exam. Respondents were selected as many as 100 people who are willing to fill out the research questionnaire. To get good analysis results, this study uses a problem-solving method, namely by using the Unified Theory Acceptance and Use of Technology (UTAUT) with various constructs. As a result, the UTAUT method explains the acceptance of CBT users with the business expectation performance (PE) construct which has a significant effect on the acceptance and use of a system (BIUS). To measure the level of variation in the change in the independent variable on the dependent variable or the highest R-Square value in the UTAUT method is $73 \%$. From these results it can be concluded that the UTAUT method is the best method used in this case study research.
\end{abstract}

Keywords: Computer Based Test (CBT); Unified Theory Acceptance and Use of Technology (UTAUT); Path Analysis, SEM PLSApplication, Hypothesis testing

\section{PENDAHULUAN}

Perkembangan teknologi informasi sangat cepat dan telah mengambil peran besar terhadap semua lini kehidupan [1]. Pada 10 (sepuluh) tahun terakhir, sistem informasi telah di implementasikan ke dalam semua organisasi, baik organisasi profit dan organisasi nirlaba. Perkembangan teknologi informasi ini telah dirasakan oleh bidang pendidikan [2]. Salah satunya dalam penelitian ini yaitu Institusi Pendidikan STIKes Elisabeth Medan yang berupaya menjadi sebuah kampus cerdas.

STIKes Elisabeth Medan sebagai salah satu institusi pendidikan juga telah menerapkan sistem informasi yang terintegrasi dan terpadu. Sistem ini dikembangkan secara bertahap dan menyeluruh. Salah satu teknologi yang dikembangkan yaitu dalam penyelenggaraan kegiatan ujian, baik berupa ujian teori maupun berupa ujian praktek. Kegiatan ujian ini dilakukan sebagai salah satu instrumen untuk menentukan kelulusan mahasiswa dalam pertengahan semester atau akhir semester. Dalam penelitian oleh Pakpahan (2016), ujian nasional dapat dilaksanakan dengan dua cara, yang pertama ujian nasional dilaksanakan dengan mekanisme secara tertulis atau Paper Based Test (PBT) dan yang kedua ujian nasional dilakukan dengan mekanisme menggunakan komputer atau disebut dengan Computer Based Test (CBT) [3].

Pengembangan pelaksanaan ujian dengan CBT diharapkan dapat meningkatkan mutu, menghemat biaya, dan menjamin ujian dilaksanakan oleh peserta dengan jujur, bersih, fleksibel, dan transparan [4]. Ujian online yang dilaksanakan dengan ujian berbasis CBT dapat meminimalisir terjadinya kebocoran soal, karena soal yang dihadapi oleh setiap peserta akan berbeda-beda untuk setiap peserta ujian. Instrumen penilaian merupakan tes yang disusun dan dikembangkan pendidik dan perlu diperhatikan beberapa aspek agar tes tersebut secara konstruksi lebih baik [5]. Kualitas tes yang disusun pendidik harus baik dan perlu upaya pengembangan agar tes tersebut lebih berkualitas paling tidak dari segi konstruksi. 
Menurut Salamah (2018), instrumen penilaian merupakan tes yang disusun dan dikembangkan pendidik dan perlu diperhatikan beberapa aspek agar tes tersebut secara konstruksi lebih baik [5]. Dalam penelitian Indriyanti (2020), Metode yang paling banyak digunakan untuk menganalisis keberhasilan penggunaan teknologi adalah metode Technology Acceptance Model (TAM) dan Unified Theory Acceptance and Use of Technology (UTAUT). Metode TAM dan UTAUT merupakan metode terbaik karena mampu menjelaskan perilaku pengguna terhadap penggunaan teknologi [6]. Helliawati (2015), melakukan penelitian perbandingan TAM dan UTAUT dalam mengukur kesuksesan penerapan sistem informasi akademik STMIK Dipanegara Makassa. Hasil penelitian menunjukkan bahwa kesuksesan penerapan sistem informasi akademik dapat dijelaskan dengan baik oleh konstruk percieved usefulness pada metode TAM dan konstruk performance ekspectancy dan facilitating condition pada metode UTAUT [7]. Dalam penelitian Winda (2019), menunjukkan bahwa kesuksesan penerapan sistem digital library dijelaskan dengan baik oleh konstruk performance ekspectancy (PE) dan facilitating condition (FC) pada metode UTAUT dan perceived usefulness (PU) pada metode TAM [8].

Untuk mengetahui dampak dari peralihan ujian berbasis PBT menjadi ujian berbasis CBT, diperlukan analisis dengan melihat seberapa besar penerimaan user terhadap pelaksanaan ujian berbasis CBT tersebut supaya kedepannya arah pengembangan dan pemanfaatan sistem dapat tepat sasaran. Dengan menggunakan teknik menyusun instrument penelitian, metode dan data yang valid, tentu akan memberikan hasil penelitian dengan tingkat kepercayaan dan akurasi yang baik. Metode yang paling banyak digunakan untuk menganalisis keberhasilan penggunaan teknologi adalah metode Unified Theory Acceptance and Use of Technology (UTAUT). Metode UTAUT merupakan metode terbaik karena mampu menjelaskan perilaku pengguna terhadap penggunaan teknologi [6][7][7].

Adapun tujuan dari penelitian ini yaitu memperoleh informasi mengenai efektivitas CBT dalam menilai ujian mahasiswa STIKes Santa Elisabeth Medan, memperoleh informasi mengenai penilaian user CBT pada kampus STIKes Santa Elisabeth Medan. Uji kasus di lakukan pada kampus STIKes Santa Elisabeth Medan dan data yang di hasilkan adalah hasil wawancara dan kuisioner pada penggunaan ujian berbasis CBT. Metode UTAUT menggunakan lima buah konstruksi yaitu: ekspektasi kinerja (performance expectancy), ekspektasi harapan (effort expectancy), pengaruh sosial (social influence), kondisi fasilitas (facilitating conditions) dan intensitas pengguna/niat penggunaan (behavioral intention) [8].

\section{METODOLOGI PENELITIAN}

\subsection{Desain Penelitian}

Dalam rangka melaksanakan penelitian, terdapat tahapan-tahapan yang dilakukan sebagaimana yang disajikan.

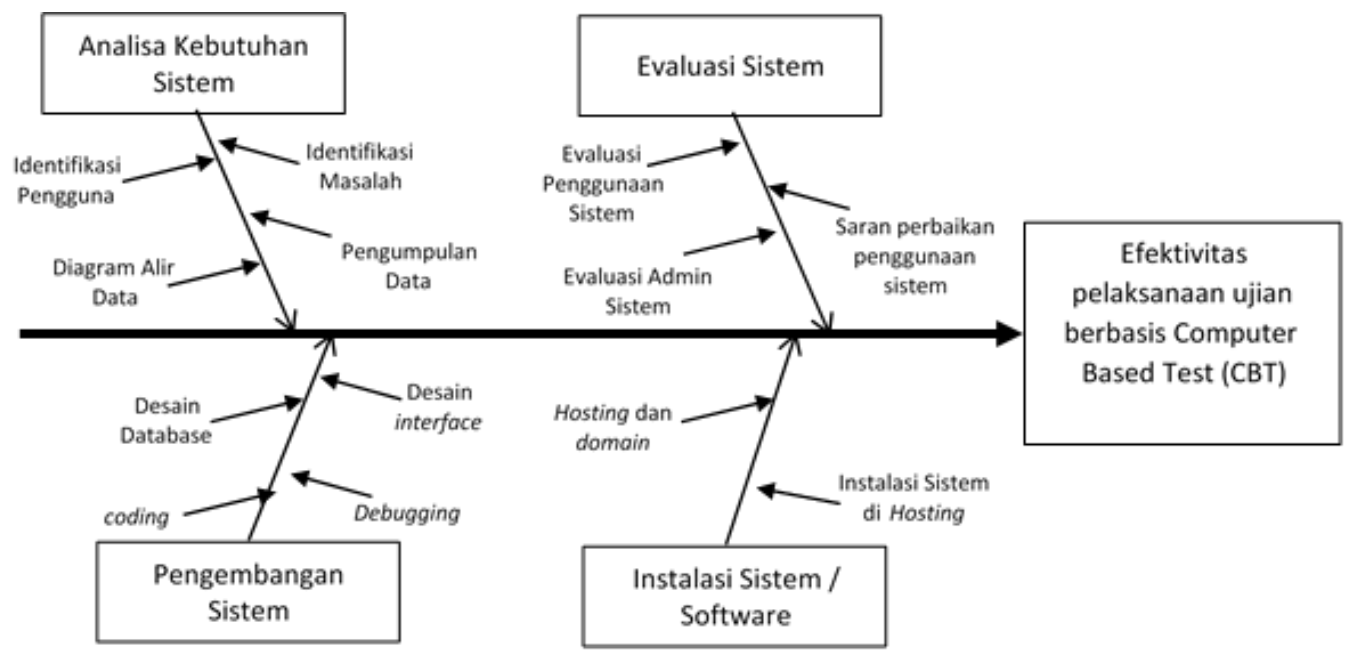

Gambar 1. Diagram Fishbone tahapan Penelitian

Metode penelitian yang digunakan adalah penelitian survei, yaitu melakukan pengumpulan informasi dengan cara menyusun daftar pertanyaan yang diajukan kepada responden [9]. Survei merupakan metode yang sangat baik untuk mengukur sikap, dan orientasi suatu masyarakat melalui berbagai kegiatan jajak pendapat [10].

\subsection{Responden dan Tempat Penelitian}

Kasus penelitian adalah sistem CBT, soal CBT, dan hasil CBT yang diuji validitas, reliabilitasnya, dan usabilitasnya. Responden yang terlibat dalam penelitian ini yaitu 100 mahasiswa dari empat program studi yang berbeda yaitu 25 mahasiswa program studi ners, 25 mahasiswa program studi D3 Keperawatan, 25 mahasiswa program studi D3 Kebidanan, 25 mahasiswa program studi Teknologi lab.medik, 25 mahasiswa program studi Manajeman Informasi kesehatan. 
Daftar pertanyaan dalam wawancara telah ditentukan terlebih dahulu sesuai dengan indikator-indikator dalam variabel UTAUT:

a. Observasi: Melakukan pengamatan secara langsung terhadap objek yang diteliti. Dalam penelitian ini pengumpulan data melalui standar operasional prosedur pelaksanaan ujian CBT di Lingkungan STIKes Elisabeth Medan.

b. Kuesioner: Kuisioner yang berisi sejumlah pernyataan tertulis yang dibuat berdasarkan metode TAM dan UTAUT. Analisis dilakukan dengan menggunakan skala likert 4 poin. Skala likert digunakan untuk mengukur sikap,pendapat, dan persepsi seseorang atau sekelompok orang tentang kejadian atau gejala sosial. Skala yang terdiri dari pernyataan dan disertai jawaban sangat setuju, setuju, tidak setuju, dan sangat tidak setuju. Alternatif jawaban tersebut diberi skor dari nilai 1 sampai 5 yaitu:

$5=$ Sangat Setuju

$4=$ Setuju

$3=$ Netral

$2=$ Tidak Setuju

$1=$ Sangat Tidak Setuju

Berikut ini tabel konstruk, indikator dan kode yang menjelaskan motode UTAUT untuk mengevaluasi penerimaan pengguna CBT [11][12] :

Tabel 1. Konstruk, Indikator dan Kode Metode UTAUT

\begin{tabular}{|c|c|c|}
\hline Konstruk & Kisi-Kisi Wawancara & Kode \\
\hline Performance Expectancy & Manfaat, kemudahan, efisien, efektif & $\mathrm{PE}$ \\
\hline Effort Expectancy & $\begin{array}{l}\text { Mudah dipelajari, mudah digunakan, } \\
\text { efektif dan efisien }\end{array}$ & $\mathrm{EE}$ \\
\hline Facilitating Condition & $\begin{array}{l}\text { Kepemilikan sumber daya, fasilitas call } \\
\text { center admin, fasilitas dari CBT }\end{array}$ & FC \\
\hline Social Influence & $\begin{array}{l}\text { Pengaruh tren, pengaruh orang terdekat, } \\
\text { lingkungan }\end{array}$ & SI \\
\hline Behavioral Intention & $\begin{array}{l}\text { Keinginan menggunakan, akan tetap } \\
\text { menggunakan dimasa depan }\end{array}$ & BI \\
\hline
\end{tabular}

\subsection{Pengolahan Data Penelitian}

Pengolahan data mengunakan teknik analisis statistik menggunakan SEM PLS dengan software SmartPLS 3.0 untuk pengujian hipotesis dan uji validitas dan reliabilitas instrumen dalam penelitian pengolahan data kuesioner yang telah diisi oleh responden. Hasil dari pengolahan data akan dijadikan bahan untuk dianalisis menggunakan beberapa teknik pengujian sehingga dapat diperoleh perbandingan metode TAM dan metode UTAUT dan mengetahui metode terbaik dalam mengevaluasi penerimaan pengguna CBT oleh peserta ujian CBT di STIKes Elisabeth Medan. Analisis metode TAM dan UTAUT berisi pengujian-pengujian data yang diperoleh dari hasil jawaban responden yang diterima. Analisis menggunakan SEM dengan model pengukuran (Outer Model), model struktural (Inner Model) dengan uji T-statistik dan R-square [13].

\subsubsection{Model Pengukuran (Outer Model)}

Model pengukuran digunakan untuk menguji validitas konstruk dan reliabilitas instrumen.

a. Uji Validitas

Uji validitas yaitu, yaitu kita mendalami persoalan otentisitas hubungan sebab dan akibat (validitas internal) dan generalisasinya untuk lingkungan eksternal (validitas eksternal). Ada beberapa uji validitas yang digunakan untuk menguji ketepatan ukuran, demi kejelasan dapat dilakukan dengan mengelompokan uji validitas ke dalam tiga bagian besar: validitas isi, validitas berdasar kriteria, dan validitas konsep. Dalam penelitian ini, pengujian validitas dilakukan dengan membandingkan nilai signifikansi 2 arah (sig 2-Tailed), jika signifikansi 2 arah (sig 2-Tailed) $<0,05$ maka pertanyaan tersebut dikatakan valid, dan juga sebaliknya jika signifikansi 2 arah (sig 2-Tailed) > 0,05 maka butir pertanyaan dikatakan tidak valid.

b. Uji Reabilitas

Metode yang sering digunakan dalam penelitian untuk uji realibilitas adalah metode Cronbach's Alpha. Apabila nilai Cronbach's Alpha $(\alpha)>0,6$ maka dapat dinyatakan bahwa variabel tersebut reliabel dan dapat dilanjutkan pada tahap analisis berikutnya.

Pada tahap ini dilakukan analisis pengukuran model (measurement model) yang terdiri dari empat tahap pengujian. Empat tahap pengujian ini terdiri dari individual item reliability, internal consistency reliability, average variance extracted, dan discriminant validit.

\subsubsection{Model Struktural (Inner Model)}

Model hipotesis UTAUT: 


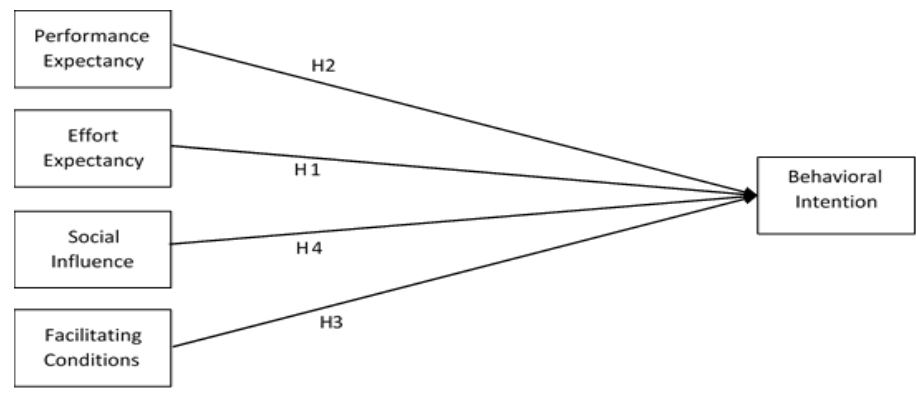

Gambar 2. Model Hipotesis Metode UTAUT

Keterangan gambar 2 diperlihatkan pada tabel 2 berikut ini:

Tabel 2. Hipotesis Penelitian Metode UTAUT

\begin{tabular}{cl}
\hline & \multicolumn{1}{c}{ Hipotesis Penelitian } \\
\hline H1 & Performance Expectancy berpengaruh positif terhadap Sikap terhadap Behavioral Intention \\
H2 & Effort Expectancy berpengaruh positif terhadap Performance Expectancy \\
H3 & Effort Expectancy berpengaruh positif terhadap Sikap terhadap Behavioral Intention \\
H4 & Social Influence berpengaruh positif terhadap Behavioral Intention \\
H5 & Facilitating Conditions berpengaruh positif terhadap Behavioral Intention \\
\hline
\end{tabular}

Pada tahap analisis model struktural ini dilakukan enam tahap pengujian, yang terdiri dari pengujian path coefficient $(\beta)$, coefficient of determination $\left(\mathrm{R}^{2}\right)$, t-test menggunakan metode bootstrapping, effect size $\left(\mathrm{f}^{2}\right)$ dan predictive relevance $\left(\mathrm{Q}^{2}\right)$

\section{HASIL DAN PEMBAHASAN}

\subsection{Deskripsi Data Uji}

Deskripsi data yang akan disampaikan berikut ini untuk memberikan gambaran secara umum mengenai penyebaran data yang telah dilakukan di lapangan. Sampel dalam penelitian ini ada 100 mahasiswa dari STIKES Elisabeth Medan. Penelitian dilakukan mulai tanggal 12 Januari hingga 19 Februari 2021. Penelitian dilakukan dengan menyebarkan kuisioner untuk mengambil data pada para mahasiswa yang pernah ujian menggunakan sistem CBT.

Penyebaran kuisioner dilakukan langsung oleh peneliti dengan mendatangi lokasi penelitian di STIKES Elisabeth Medan. Penyebaran kuisioner secara langsung ini dilakukan untuk memperoleh tingkat pengembalian kuisioner keseluruhan. Pembagian dilakukan secara random tetapi tetap diusahakan tersebar untuk semua prodi yang ada.

\subsection{Hasil Analisis Outer Model (Pengukuran) UTAUT}

Model pengukuran digunakan untuk menguji validitas konstruk dan reliabilitas instrumen. Uji validitas dilakukan untuk mengetahui kemampuan instrumen penelitian dalam mengukur apa yang seharusnya diukur [14]. Sedangkan uji reliabilitas digunakan untuk mengukur konsistensi alat ukur dalam mengukur model atau mengukur konsistensi responden dalam menjawab pertanyaan dalam kuesioner [15].

Pada tahap ini dilakukan analisis pengukuran model (measurement model) yang terdiri dari empat tahap pengujian. Empat tahap pengujian ini terdiri dari individual item reliability, internal consistency reliability, average variance extracted, dan discriminant validity. Berikut adalah hasil analisis pengukuran model yang dijelaskan dalam empat tahap.

a. Pengujian Individual Item Readibility

Individual Item Reliability dapat diketahui dengan melihat Standardized Loading Factor yang menggambarkan besarnya korelasi antara setiap item pengukuran (indikator) dengan konstruknya. Setelah melakukan pengukuran menggunakan SmartPLS maka diketahui nilai Loading Factor. Nilai ini dapat dikatakan ideal atau valid sebagai indikator dalam mengukur konstruk jika di atas 0,7.

Tabel 3. Hasil dengan Uji Loading Factor UTAUT

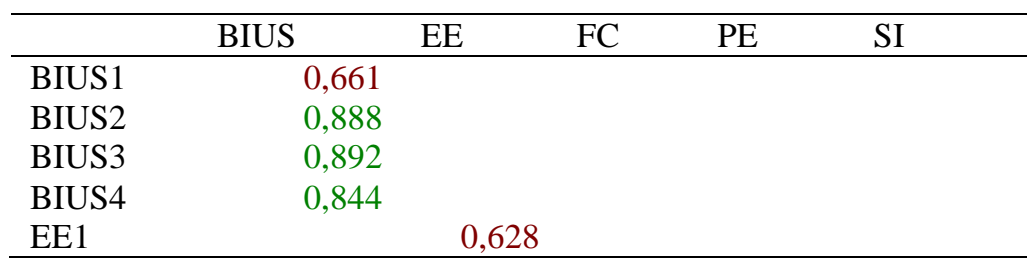


JURNAL MEDIA INFORMATIKA BUDIDARMA

Volume 5, Nomor 2, April 2021, Page 532-539

ISSN 2614-5278 (media cetak), ISSN 2548-8368 (media online)

Available Online at https://ejurnal.stmik-budidarma.ac.id/index.php/mib

DOI 10.30865/mib.v5i2.2924

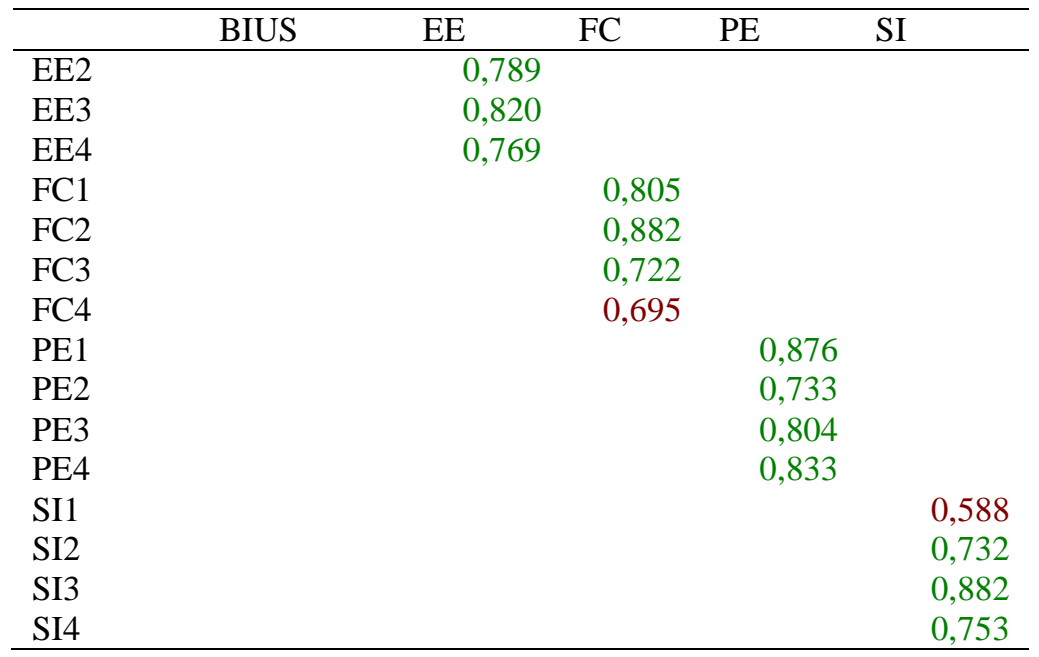

Dari hasil uji loading factor menggunakan smartpls 3.0 dapat dilihat bahwa terdapat 3 indikator yang di bawah 0,7 yaitu BIUS1, EE1 dan FC4. Akan tetapi peneliti tidak menghapus indikator tersebut dikarenakan nilai composite reliability masih di atas 0,7 .

b. Uji Internal Consistency Reliability

Pengujian ini dilakukan dengan melihat nilai composite reliability (CR) dengan batas ambang di atas 0,7. Hasil penelitian menunjukkan bahwa semua indikator memiliki nilai di atas 0,7 hal tersebut dapat dilihat pada tabel 4 yang menunjukkan nilai composite reliability pada tiap indikator. Hal tersebut menandakan bahwa indikator dapat memenuhi syarat.

Tabel 4. Nilai Composite Reliability UTAUT

\begin{tabular}{ll}
\hline \multicolumn{3}{c}{ Composite Reliability } \\
\hline BIUS & 0,895 \\
EE & 0,840 \\
FC & $\mathbf{0 , 8 6 0}$ \\
PE & $\mathbf{0 , 8 8 6}$ \\
SI & 0,831 \\
\hline
\end{tabular}

c. Average Variance Extracted UTAUT

Pengujian ketiga yaitu Average Variance Extracted (AVE) yaitu pengujian yang menghasilkan gambaran besar atau keragaman variabel manifes (indikator) yang dapat dikandung oleh variabel laten (konstruk). Nilai AVE dapat dikatakan baik atau valid jika pengukuran menunjukkan angka di atas 0,5 . Hal ini dapat diartikan bahwa variabel laten (konstruk) dapat menjelaskan rata-rata lebih dari setengah variance dari indikatorindikatornya.

Tabel 5. Nilai Average Variance Extracted (UTAUT)

\begin{tabular}{ll}
\hline \multicolumn{2}{c}{ Average Variance Extracted (AVE) } \\
\hline BIUS & 0,683 \\
EE & 0,570 \\
FC & 0,607 \\
PE & 0,661 \\
SI & 0,556 \\
\hline
\end{tabular}

Dapat dilihat bahwa semua variabel yang di uji memiliki nilai AVE di atas 0,5 sehingga memenuhi syarat dan tidak ada masalah dalam uji nilai AVE. Hal ini dapat dilihat pada tabel 5 yang menunjukkan nilai AVE pada tiap variabel.

d. Discriminant Validity UTAUT

Validitas diskriminan terjadi jika dua instrumen yang berbeda mengukur dua konstruk yang diprediksi tidak berkorelasi menghasilkan skor yang memang tidak berkorelasi. Pengujian ini dilakukan melalui dua tahap pemeriksaan cross loading, yaitu cross loading antar indikator dan cross loading Fornell-Lacker's.

Pemeriksaan cross loading tiap indikator dilakukan dengan membandingkan korelasi indikator dengan variabelnya dan variabel blok lainnya. Bila korelasi antara indikator dengan variabelnya lebih tinggi dari korelasi dengan variabel blok lainnya, hal ini menunjukkan konstruk tersebut memprediksi ukuran pada blok mereka lebih baik dari blok lainnya. Sedangkan pemeriksaan cross loading Fornell-Lacker's dilakukan dengan melihat nilai akar AVE yang harus lebih tinggi daripada korelasi antara variabel dengan variabel lainnya. Hasil pengujian dapat dilihat pada tabel. 
JURNAL MEDIA INFORMATIKA BUDIDARMA

Volume 5, Nomor 2, April 2021, Page 532-539

ISSN 2614-5278 (media cetak), ISSN 2548-8368 (media online)

Available Online at https://ejurnal.stmik-budidarma.ac.id/index.php/mib DOI 10.30865/mib.v5i2.2924

Tabel 6. Hasil Uji Discriminant Validity (Cross Loading) UTAUT

\begin{tabular}{lrrrrr}
\hline & BIUS & EE & \multicolumn{2}{c}{ FC } & PE \\
\hline BIUS1 & 0,661 & 0,557 & 0,542 & 0,477 & 0,644 \\
BIUS2 & 0,888 & 0,658 & 0,491 & 0,725 & 0,563 \\
BIUS3 & 0,892 & 0,643 & 0,523 & 0,743 & 0,563 \\
BIUS4 & 0,844 & 0,708 & 0,529 & 0,703 & 0,576 \\
EE1 & 0,432 & 0,628 & 0,284 & 0,532 & 0,384 \\
EE2 & 0,718 & 0,789 & 0,470 & 0,689 & 0,596 \\
EE3 & 0,582 & 0,820 & 0,619 & 0,559 & 0,695 \\
EE4 & 0,569 & 0,769 & 0,547 & 0,496 & 0,567 \\
FC1 & 0,452 & 0,563 & 0,805 & 0,492 & 0,600 \\
FC2 & 0,577 & 0,559 & 0,882 & 0,657 & 0,603 \\
FC3 & 0,352 & 0,398 & 0,722 & 0,436 & 0,466 \\
FC4 & 0,520 & 0,467 & 0,695 & 0,526 & 0,590 \\
PE1 & 0,748 & 0,665 & 0,606 & 0,876 & 0,599 \\
PE2 & 0,528 & 0,580 & 0,477 & 0,733 & 0,540 \\
PE3 & 0,587 & 0,565 & 0,577 & 0,804 & 0,516 \\
PE4 & 0,735 & 0,654 & 0,579 & 0,833 & 0,504 \\
SI1 & 0,431 & 0,542 & 0,463 & 0,378 & 0,588 \\
SI2 & 0,567 & 0,485 & 0,456 & 0,469 & 0,732 \\
SI3 & 0,576 & 0,594 & 0,629 & 0,526 & 0,882 \\
SI4 & 0,502 & 0,640 & 0,633 & 0,590 & 0,753 \\
\hline
\end{tabular}

Tabel 7 menunjukkan bahwa nilai cross loading pada indikator yang berwarna lebih besar dari pada korelasi dengan konstruk blok lainnya. Hal ini dapat diartikan bahwa setiap konstruk berkorelasi kuat dengan masingmasing indikatornya. Selain itu dalam uji Validitas diskriminan juga dapat dilakukan dengan cara cross loading Fornell-Lacker's. Tabel 4.14 dapat menunjukkan hasilnya.

Tabel 7. Hasil Uji Discriminant Validity (Cross Loading Fornell-Lacker's)

\begin{tabular}{lrrrrrr}
\hline & BIUS & EE & \multicolumn{2}{c}{ FC } & PE & \multicolumn{1}{c}{ SI } \\
\hline BIUS & 0,827 & & & & \\
EE & 0,778 & 0,755 & & & \\
FC & 0,626 & 0,646 & 0,779 & & \\
PE & 0,810 & 0,760 & 0,691 & 0,813 & \\
SI & 0,702 & 0,754 & 0,732 & 0,661 & 0,746 \\
\hline
\end{tabular}

Tabel 7 menunjukkan bahwa nilai akar AVE lebih tinggi dari pada korelasi antara konstruk lainnya. Berdasarkan hasil pemeriksaan dua tahap cross loading yang dilakukan sebelumnya dapat disimpulkan bahwa tidak ada masalah dalam uji discriminant validity.

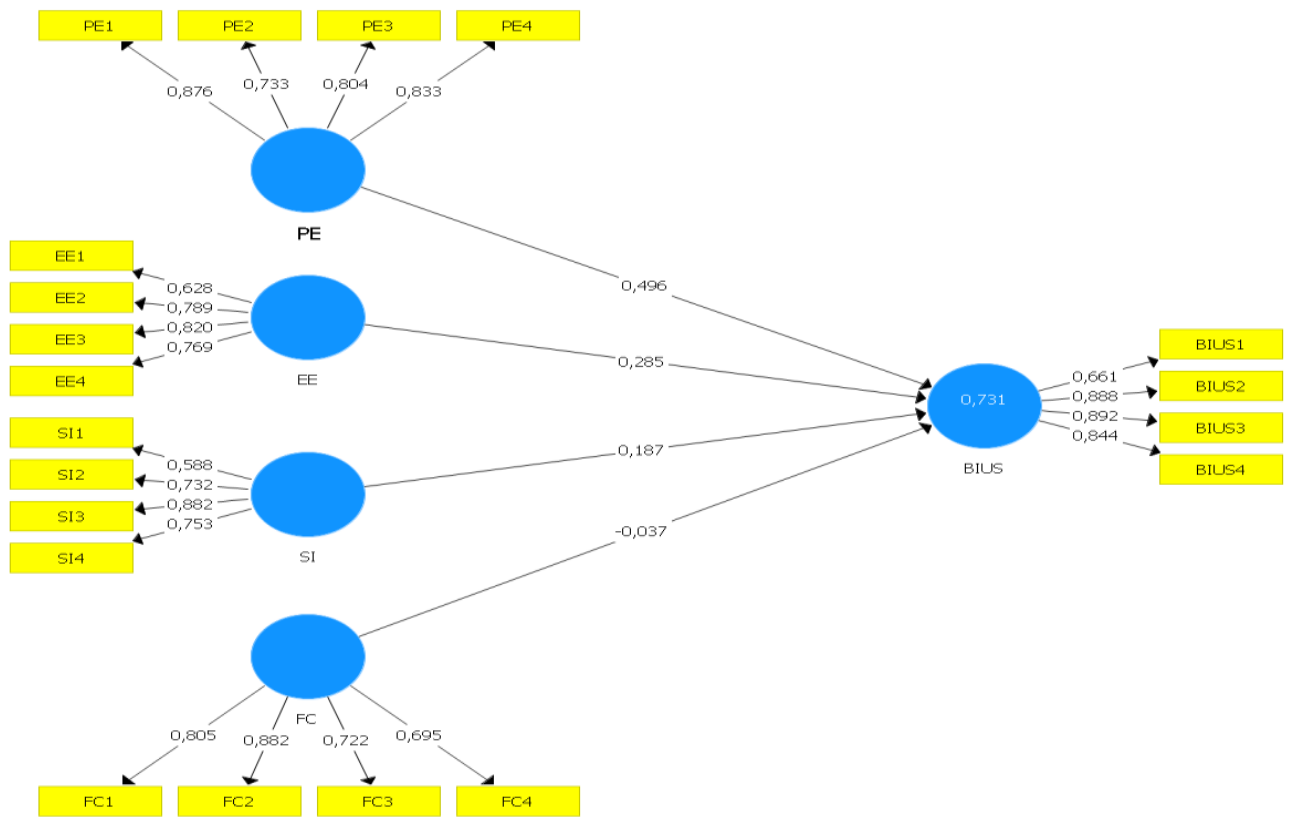

Gambar 3. Hasil Analisis Outer Model UTAUT dengan SmartPLS 3 
Kesimpulan dari hasil analisis pengukuran model bahwa model tersebut memenuhi syarat, adapun syaratnya adalah uji individual item reliability, uji internal consistency reliability, average variance extracted dan discriminant validity.

Pengujian koefisien determinasi dilakukan untuk menjelaskan varian dari tiap target variabel yang dianggap dipengaruhi oleh variabel lain dalam model (endogenous variabel) [16]. Gambar 3 menunjukkan hasil uji Coefficient of Determination $\left(\mathrm{R}^{2}\right)$. Dapat dilihat hasil uji coefficient of determination dari BIUS memiliki nilai 0,731. Maka dapat disimpulkan bahwa variabel PE, EE, FC dan SI menjelaskan 73,1\% varian dari BIUS.

\subsection{Hasil Analisis Model Struktural (Inner Model) UTAUT}

Terdapat 4 jalur yang akan diteliti dalam penelitian ini, dari keempat jalur tersebut terdapat 1 jalur yang tidak signifikan (insignificant) yaitu $\mathrm{FC} \rightarrow \mathrm{BIUS}$. Hal ini dikarenakan memiliki hasil path coefficient di bawah 0,1 . Hasil uji path coefficient $(\beta)$ diperlihatkan pada tabel 8. Hasil uji Coefficient of Determination $\left(\mathrm{R}^{2}\right)$.

Hasil uji T-test dilakukan dengan metode bootstrapping pada SmartPLS 3.0 dengan level of confident 5\% $(0,05)$, hal ini dilakukan untuk menguji hipotesis-hipotesis pada penelitian. Dengan level of confident $5 \%(0,05)$ maka hipotesis tersebut akan diterima jika memiliki t-test lebih besar dari 1,96. Tabel 8 menunjukkan bahwa terdapat 4 hipotesis dengan 2 diantaranya diterima sisanya ditolak.

Tabel 8. Hasil Uji Outer Model dan Inner Model dan t-test UTAUT

\begin{tabular}{cccccc}
\hline & Hipotesis & \multirow{2}{*}{ T-test } & \multicolumn{2}{c}{ Keterangan } \\
No & Jalur & \multicolumn{1}{c}{ ( } & & & \\
\hline $\mathrm{H} 1$ & $\mathrm{EE} \rightarrow$ BIUS & 0,285 & 2,955 & Significant & Diterima \\
$\mathrm{H} 2$ & $\mathrm{PE} \rightarrow$ BIUS & 0,496 & 4,686 & Significant & Diterima \\
$\mathrm{H} 3$ & $\mathrm{FC} \rightarrow \mathrm{BIUS}$ & $-0,037$ & 0,143 & Insignificant & Ditolak \\
$\mathrm{H} 4$ & $\mathrm{SI} \rightarrow$ BIUS & 0,187 & 1,466 & Significant & Ditolak \\
\hline
\end{tabular}

Keterangan:

H1 : Apakah Effort Expectancy (EE) berpengaruh secara signifikan terhadap Behavioral intention to use the system (BIUS)?

Berdasarkan pengajuan hipotesis pertama diketahui bahwa H1 yang diajukan dapat diterima. Output path coefficient menunjukkan bahwa nilai t statistik untuk konstruk EE terhadap BIUS yaitu 2,955 sehingga pengaruh yang diberikan EE terhadap BIUS terbukti signifikan. Nilai koefisien variabel laten EE pada output path coefficient sebesar 0,285 yang berarti terdapat pengaruh positif sebesar 28,5\% terhadap konstruk BIUS. Semakin tinggi tingkat kemudahan dalam menggunakan suatu sistem semakin tinggi pula penerimaan dan penggunaan suatu sistem. Secara logis dapat dipersepsikan semakin mudah penggunaan sistem akan semakin diterima dan digunakan oleh pengguna.

H2 : Apakah Performance Expectancy (PE) berpengaruh secara signifikan terhadap Behavioral intention to use the system (BIUS)?

Berdasarkan pengajuan hipotesis pertama diketahui bahwa $\mathrm{H} 2$ yang diajukan dapat diterima. Output path coefficient menunjukkan bahwa nilai t statistik untuk konstruk PE terhadap BIUS yaitu 4,686 sehingga pengaruh yang diberikan PE terhadap BIUS terbukti signifikan. Nilai koefisien variabel laten PE pada output path coefficient sebesar 0,496 yang berarti terdapat pengaruh positif sebesar 49,6\% terhadap konstruk BIUS. Semakin tinggi keuntungan yang didapatkan oleh pengguna maka akan semakin tinggi pula penerimaan dan penggunaan suatu sistem. Secara logis dapat dipersepsikan semakin menguntungkan suatu sistem akan semakin diterima dan digunakan oleh pengguna.

H3 : Apakah Social Influence (SI) berpengaruh secara signifikan terhadap Behavioral intention to use the system (BIUS)?

Berdasarkan pengajuan hipotesis pertama diketahui bahwa H3 yang diajukan ditolak. Output path coefficient menunjukkan bahwa nilai t statistik untuk konstruk SI terhadap BIUS yaitu 0,143 sehingga pengaruh yang diberikan SI terhadap BIUS insignifikan. Nilai koefisien variabel laten SI pada output path coefficient sebesar -0,037 yang berarti terdapat pengaruh negatif sebesar 3,7\% terhadap konstruk BIUS. Semakin tinggi pengaruh yang diberikan oleh orang-orang yang penting bagi pengguna, semakin turun penerimaan dan penggunaan suatu sistem. Secara logis dapat dipersepsikan dorongan oleh orang lain untuk menggunakan sistem tidak akan mempengaruhi seseorang menggunakan sistem CBT.

H4 : Apakah Facilitating Conditions (FC) berpengaruh secara signifikan terhadap Behavioral intention to use the system (BIUS)?

Berdasarkan pengajuan hipotesis pertama diketahui bahwa $\mathrm{H} 4$ yang diajukan ditolak. Output path coefficient menunjukkan bahwa nilai t statistik untuk konstruk FC terhadap BIUS yaitu 1,466 sehingga pengaruh yang diberikan FC terhadap BIUS insignifikan. Nilai koefisien variabel laten EE pada output path coefficient sebesar 0,187 yang berarti terdapat pengaruh positif sebesar 18,7\% terhadap konstruk BIUS. Semakin tinggi tingkat kemudahan dalam menggunakan suatu sistem semakin tinggi nilai kepercayaan pengguna terhadap infrastruktur organisasional dan teknikal yang tersedia semakin tinggi pula penerimaan 
dan penggunaan suatu sistem. Hasil ini menunjukkan bahwa semakin lengkap fasilitas yang mendukung dalam penggunaan sistem tidak memengaruhi sikap pengguna menggunakan sistem CBT. Peneliti menyimpulkan hal ini karena kelengkapan fasilitas bukan tujuan utama dari responden, tetapi lebih mengharapkan sistem yang merespon baik jawaban mereka.

\section{KESIMPULAN}

Hasil penelitian menunjukkan bahwa metode UTAUT konstruk performace ekspectancy (PE) yang paling berpengaruh atau lebih kuat dalam menjelaskan penerimaan sistem CBT di lingkungan STIKES Elisabeth Medan. Hal ini berarti bahwa sistem CBT yang diterapkan memiliki performace yang dapat diandalkan guna membantu pekerjaan dan proses ujian. Metode UTAUT menjelaskan penerimaan CBT dapat di jelaskan oleh konstruk ekspektasi usaha ekspektasi kinerja (PE) berpengaruh signifikan terhadap penerimaan dan penggunaan suatu sistem (BIUS) yang memiliki T-Statistik 4,686 dan R-Square: 73\%. Yang artinya niat prilaku dalam menggunakan sistem dapat dijelaskan oleh konstruk ekspektasi kinerja (performance expectancy), ekspektasi usaha (effort expectancy), pengaruh social (social influence), kondisi fasilitas (facilitating condition) sehingga terdapat niat prilaku pengguna menggunakan sistem sebesar 73\% hal ini membuktikan bahwa penerimaan sistem CBT telah di terima dan telah berhasil diterapkan karena memiliki banyak kegunaan dalam membantu pihak di lingkungan STIKES Elisabeth Medan dalam melaksanakan kegiatan ujian. Untuk menambah persentase keberhasilan dari metode UTAUT bisa ditambahkan konstruk dan indikator dari masing-masing konstruk serta ditambah jumlah respondennya.

\section{UCAPAN TERIMAKASIH}

Terimakasih kepada Universitas Potensi Utama sebagai yang telah memberikan teori-teori yang berguna dalam menyusun peneltian ini. Begitu juga pada Staf Institut Teknologi dan Bisnis Indonesia Kampus Milenial yang telah sangat berjasa memberikan bantuan pengetahuan dalam penyusunan penelitian ini. Terimakasih juga kepada STIKes Elisabeth Medan yang telah bersedia menjadi lokasi kegiatan survei penelitian ini.

\section{REFERENCES}

[1] F. J. Kaunang et al., Konsep Teknologi Informasi. Yayasan Kita Menulis, 2021.

[2] M. P. Saptono and H. Widjasena, "Perancangan dan Implementasi Aplikasi Ujian Sekolah Berbasis Komputer Atau Computer Based Test (CBT) Di SMK Negeri 1 Kabupaten Sorong," Electro Luceat, vol. 5, no. 2, pp. 5-13, 2019.

[3] R. Pakpahan, "Model ujian nasional berbasis komputer: manfaat dan tantangan," J. Pendidik. dan Kebud., vol. 1, no. 1, pp. 19-35, 2016.

[4] A. B. Akny, "Mewujudkan Good Governance melalui Reformasi Birokrasi di Bidang SDM Aparatur untuk Peningkatan Kesejahteraan Pegawai,” Jejaring Adm. Publik J. Ilmiah, Univ. Airlangga, vol. 6, no. 1, pp. 416-427, 2014.

[5] U. Salamah, "Penjaminan Mutu Penilaian Pendidikan," J. Eval., vol. 2, no. 1, pp. 274-293, 2018.

[6] T. W. Indriyanti, E. Ermawati, N. Ichsan, and H. Fatah, "Analisis Perbandingan Metode TAM dan UTAUT dalam Mengukur Kesuksesan Penggunaan Aplikasi Ojek Online,” J. Interkom, vol. 14, no. 4, 2020.

[7] H. Hamrul, B. Soedijono, and A. Amborowati, "Analisis perbandingan metode TAM dan UTAUT dalam mengukur kesuksesan penerapan sistem informasi akademik (studi kasus penerapan sistem informasi STMIK dipanegara Makassar)," in Seminar Nasional Informatika (SEMNASIF), 2015, vol. 1, no. 1.

[8] W. Erika, "ANALISIS PERBANDINGAN METODE TAM (Technology Acceptance Model) DAN UTAUT (Unified of Acceptance and Use of Technology) TERHADAP PERSEPSI PENGGUNA SISTEM INFORMASI DIGITAL LIBRARY (Studi Kasus: Universitas Pembangunan Panca Budi Medan),” J. Mahajana Inf., vol. 4, no. 1, pp. 78-83, 2019.

[9] A. Anggito and J. Setiawan, Metodologi penelitian kualitatif. CV Jejak (Jejak Publisher), 2018.

[10] N. Pranawati, "Survei Keterlaksanaan Kurikulum 2013 Pada Mata Pelajaran Penjasorkes Di SMP Sasaran Kota Mojokerto," J. Pendidik. Olahraga dan Kesehat., vol. 2, no. 3, 2014.

[11] T. Handayani and S. Sudiana, "Analisis penerapan model UTAUT (Unified Theory of Acceptance and Use of Technology) terhadap perilaku pengguna sistem informasi (studi kasus: sistem informasi akademik pada STTNAS Yogyakarta)," Angkasa J. Ilm. Bid. Teknol., vol. 7, no. 2, pp. 165-180, 2015.

[12] M. S. M. Diningrat, B. S. WA, and H. Henderi, "EVALUASI PENERIMAAN APLIKASI MOBILE BANKING BNI TERHADAP MINAT NASABAH MENGGUNAKAN UTAUT (STUDI KASUS: BNI CABANG UGM)," J. Inf., vol. 5, no. 4, pp. 9-13, 2019.

[13] K. A. T. Wibowo, "Faktor-Faktor yang Mempengaruhi Penerimaan Tiga Portal Web Perguruan Tinggi Swasta dengan Metode UTAUT Dan TTF." Universitas Islam Indonesia, 2019.

[14] Z. Arifin, "Kriteria instrumen dalam suatu penelitian," J. Theorems (The Orig. Res. Math., vol. 2, no. 1, 2017.

[15] M. Dhamayanti, A. D. Rachmawati, N. Arisanti, E. P. Setiawati, V. K. Rusmi, and N. Sekarwana, "Validitas dan reliabilitas kuesioner skrining kekerasan terhadap anak 'ICAST-C' versi bahasa indonesia," J. Keperawatan Padjadjaran, vol. 5, no. 3, 2018.

[16] J. Jufrizen and A. S. P. Lubis, "Pengaruh Kepemimpinan Transformasional dan Kepemimpinan Transaksional terhadap Kinerja Pegawai Dengan Locus Of Control Sebagai Variabel Moderating," Maneggio J. Ilm. Magister Manaj., vol. 3, no. 1, pp. 41-59, 2020. 